\title{
Mechanical Strengthening and Microstructural Evolutions of Ni-B Based Hardfacing Alloys Influenced by Titanium Additions
}

\author{
Zeblon Meshack Ebimobowei ${ }^{1}$, Ajenifuja Emmanuel ${ }^{2,3,}$, , Ajao John Adegbindin ${ }^{2}$ \\ ${ }^{1}$ Department of Physics and Engineering Physics, Obafemi Awolowo University, Ile-Ife, Nigeria \\ ${ }^{2}$ Centre for Energy Research and Development, Obafemi Awolowo University, Ile-Ife, Nigeria \\ ${ }^{3}$ Department of Chemical, Metallurgical and Materials Engineering, Tshwane University of Technology, Pretoria, South Africa \\ Email address: \\ eajenifuja@gmail.com (A. Emmanuel), ajenifujae@tut.ac.za (A. Emmanuel) \\ ${ }^{*}$ Corresponding author
}

\section{To cite this article:}

Zeblon Meshack Ebimobowei, Ajenifuja Emmanuel, Ajao John. Mechanical Strengthening and Microstructural Evolutions of Ni-B Based Hardfacing Alloys Influenced by Titanium Additions. Advances in Materials. Vol. 8, No. 2, 2019, pp. 41-47.

doi: 10.11648/j.am.20190802.11

Received: January 31, 2019; Accepted: March 11, 2019; Published: April 13, 2019

\begin{abstract}
The microstructure and mechanical behaviour of Ni-B binary alloys have been enhanced in this study by varied titanium additions. The alloys investigated were chosen from the nickel-rich region of the Ni-B-Ti system. The microstructure of the alloys was examined using Optical Microscope (OM) and Scanning Electron Microscope (SEM) equipped with Energy Dispersive X-ray Analyzer (EDXA). The addition of titanium led to the formation of various complex phases and a ternary phase $\tau$ was observed in the study. The addition of titanium to the Ni-B alloys was found to enhance the mechanical properties of the ternary alloys. Microhardness value of the alloys was observed to increase from $216.2 \mathrm{HV}$ with zero Ti in Ni-B alloys to $1530.7 \mathrm{HV}$ in alloys with $11 \mathrm{wt}$. \% Ti. The stiffness of the alloys was also found to increase as deduced from elastic modulus value of 513.77 to $1046.51 \mathrm{~N} / \mathrm{m}^{2}$ in Alloys C. Remarkable improvement in physical properties of the Ni-based ternary alloys is due to the formation of various hard boride phases and grain size reduction occasioned by the increase in titanium content.
\end{abstract}

Keywords: Ni-B Alloys, Ti Addition, Microstructure, Microhardness, Ternary Alloy, Stiffness

\section{Introduction}

Due to the inability of materials to meet the need of engineers, surface treatments of materials become pertinent for their optimum performance. Thus, recently the problem of wear, abrasion, hot corrosion as well as poor hardness and poor stiffness of materials have been addressed by surface treatments and hardfacing techniques [1-6]. Hardfacing is a metalworking process where harder or tougher material is applied to a base metal. It generally takes the form of specialized electrodes for arc welding or filler rod for oxyacetylene. Hardfacing technique involves the preparation and application of hard alloy coatings on surface of materials. These alloys usually contain several hard phases (borides, carbides and silicides) made up of titanium, chromium, vanadium etc. and non-metals like boron, carbon and silicon.
Though nickel, cobalt or iron can be used as the base material for these alloys, nickel is often chosen because of its selffluxing properties at high temperature [3, 7-8]. The distribution of the borides, carbides and silicides in the nickel matrix are the major source of the wear, hot corrosion, abrasive resistance as well as enhanced hardness and stiffness of the alloys.

In the study of phase transitions in some nickel-rich nickel-boron-titanium hard alloys, Ajao [9] reported the microstructure of Ni-B-Ti alloys and the crystallographic orientation relationships between nickel and the boride phases. Solid-state transformation of the ternary phase was observed in his study. Recently, Viega et al. [10] reported the properties and applications of titanium alloys. It was concluded that titanium alloys are practically applicable in aerospace, automotive and biomedical industries; thanks to their outstanding properties. Studies have also shown that 
titanium, chromium, vanadium enhances the wear, abrasion and hot corrosion resistance; and increases the hardness, stiffness and high temperature compressive strength of alloys containing boron through the formation of hard boride phases [11-14]. It has been reported that boron depresses the melting point of the base alloy mixture and plays a critical role in self-fluxing properties [15]. Recently, An et al. [16] reported the interfacial structure and mechanical properties of surface iron-nickel alloying layer in pure iron fabricated by surface mechanical attrition alloy treatment (SMAAT). A refined Fe/Ni alloy layer of about $50 \mu \mathrm{m}$ was prepared on pure iron, and it was reported that intermetallic/alloy phases were formed and the diffusion activation energy was reduced; the formed alloy reduces fatigue wear effect and improve friction and wear properties to a large extent. In some other studies, eutectoid transformation of some phases in nickel-based hard alloys have been reported $[9,11,17,18]$.

Ni-B alloy coatings possess remarkable properties like high wear resistance, high hardness and attractive corrosion and abrasive resistance properties [19, 20-22]. Also, Ni-B coatings have properties which include: lubricity, uniform thickness, attractive ductility, anti-bacterial property, good electrical properties, low porosity, superior electromagnetic and bonding [23-28]. Because of these attractive properties, interests in $\mathrm{Ni}-\mathrm{B}$ based alloys continue to grow in different area and have been applied practically in many highly technological industries such as petroleum, automobile, nuclear, aerospace, computer, optics, textile, food, etc. industries [29-34]. In some other instances, Ni-Cr-B-C group is taken as the primary composition of nickel-based alloys. Different alloy elements lead to different degrees of hardness. Nickel alloys also resist wear and corrosion well, and are cheaper than cobalt alloys. Controlled amounts of carbide powders such as tungsten carbide, chromium carbide and niobium carbide, have been added to $\mathrm{Co}$ and Ni-based alloys. These have shown to improve the physical properties of the hardfacing layer, also exhibit an enhanced performance in high-temperature environments [35-37]. Titanium possesses high hardness, specific strength, low thermal conductivity, relatively low density, high reactivity with a variety of elements and good corrosion resistance, among other attractive properties [38-41]. Titanium is known to be a very important additive in Ni-B based binary and ternary superalloys for wear resistance applications due to its formation of $\mathrm{TiB}_{2}-\mathrm{Ni}$ compacts and coatings [42-45]. As a result of these unique properties of titanium, it is important to study the addition of titanium with Ni-B alloys for improved performance. To the best of the knowledge of the authors, not much studies have been carried out on $\mathrm{Ti}$ additions in Ni-B system and few reports are currently available on the influence of titanium on physical properties of Ni-B alloys $[46,47]$. The foregoing thereby stimulates the interest in the present study. The aim of the work was to prepare Ni-based ternary alloy with varied additions Ti additions using electric furnace melting, and hence determine the effect of titanium additions on the microstructure and the mechanical properties of the alloy samples.

\section{Materials and Methods}

\subsection{Preparation of the Alloys}

A binary control sample of $\mathrm{Ni}-10 \mathrm{~B}$ was prepared separately, and the ternary $\mathrm{Ni}-\mathrm{B}-\mathrm{Ti}$ alloys at different compositions of titanium (2-11 wt. \%). The components of the alloy samples were pure nickel and binary Ni-B containing 10 wt. \% B and pure titanium (99.99\% pure). The components of each alloy were accurately weighed and melted in an electric furnace. Shown in Figure 1 is the equilibrium phase diagram for the Ni-B-Ti system by Schobel and Stadelmaier [48] and the positions of the alloys studied are identified. The chemical compositions of the alloys are presented in Table 1.

\subsection{Characterization of the Alloys}

Metallographic observation of the alloys was done by optical and scanning electron microscopes equipped with energy dispersive X-ray analysis system. Etching of the samples were done before SEM analysis. The etchant consists of $5 \mathrm{~g} \mathrm{FeCl}_{3}+10 \mathrm{ml} \mathrm{HCl}$ dissolved in $50 \mathrm{ml} \mathrm{H}_{2} \mathrm{O}$. Micro-hardness tests were performed on the alloys at the Engineering Development Institute (EMDI), Akure, Nigeria, while compression tests were performed on the alloys with the use of the Instron machine at Centre for Energy Research and Development (CERD), Obafemi Awolowo University, Ile-Ife, Nigeria.

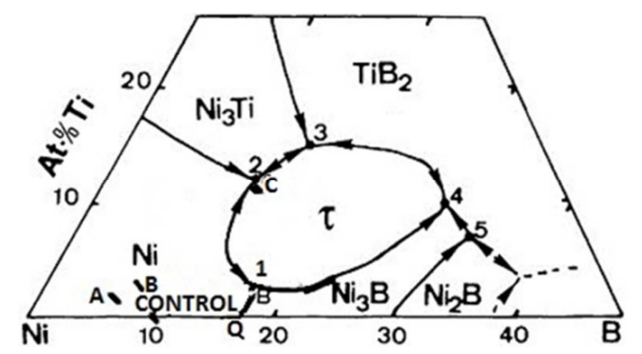

Figure 1. The liquidus projection of the Ni-B-Ti ternary system [48].

Table 1. Chemical compositions (wt. \%) of the alloys.

\begin{tabular}{llll}
\hline \multirow{2}{*}{ Sample } & \multicolumn{4}{l}{ Chemical compositions (wt. \%) } \\
\cline { 2 - 4 } & $\mathbf{N i}$ & $\mathbf{B}$ & $\mathbf{T i}$ \\
\hline Control & 90 & 10 & - \\
Alloy A & 93 & 5 & 2 \\
Alloy B & 91 & 6 & 3 \\
Alloy C & 82 & 7 & 11 \\
\hline
\end{tabular}

\section{Results and Discussion}

\subsection{Microstructure of the Alloys}

The scanning electron and optical micrographs of the control sample are shown in Figures $2 \mathrm{a}$ and $2 \mathrm{~b}$ respectively. The primary Ni $(\alpha)$ phases can be seen bounded by strips of $\mathrm{Ni}-\mathrm{Ni}_{3} \mathrm{~B}$ phases. However, a drastic change in the microstructure can be observed for the Ni-B alloys 
containing Ti additions. For Alloy A with 2 wt. \% Ti addition and quenched from the liquidus, the primary phase observed in both SEM and optical microscope images is the block-like $\mathrm{Ni}(\alpha)$ phase shown in Figures $3 \mathrm{a}$ and $3 \mathrm{~b}$. This phase was surrounded by wider binary eutectic phase $\mathrm{Ni}-\mathrm{Ni}_{3} \mathrm{~B}$. The quenched Alloy B with 3 wt. \% Ti shows clearly the presence of the binary eutectic $\mathrm{Ni}-\mathrm{Ni}_{3} \mathrm{~B}$ as the primary phase (Figures $4 \mathrm{c}$ and $4 \mathrm{~d})$. The primary $\mathrm{Ni}-\mathrm{Ni}_{3} \mathrm{~B}$ phase is surrounded by $\mathrm{Ni}_{3} \mathrm{~B}$ phase. Meanwhile, the elemental compositions of the identified phases in the microstructures were analyzed with EDXA and the results shown in spectra images, Figures 4a, $4 \mathrm{~b}$ and $4 \mathrm{c}$ for $\mathrm{Ni}(\alpha), \mathrm{Ni}-\mathrm{Ni}_{3} \mathrm{~B}$ and $\mathrm{Ni}_{3} \mathrm{~B}$ respectively. It should be noted that though the elemental composition of the analyzed phases in the control sample is similar to that of Alloys A and B with titanium content, the primary phase observed in the morphology was the $\mathrm{Ni}(\alpha)$ phase (Figures $2 \mathrm{a}$ and $2 b$ ). The absence of Ti in the analyzed phases of Alloy A and $\mathrm{B}$ might be due to the fact the Ti content was below the detection limit. However, due to the microstructural changes observed, we can therefore imply that the additions of titanium have influence on the phase transformations of the alloys, which encouraged a shift from the hypoeutectic to the hypereutectic region during quenching in air. Similar observation has been reported by Ajao [9] in his study of NiB-V ternary system.

A distinct and complete evolution in the microstructure can be observed for Alloy $\mathrm{C}$ containing $11 \mathrm{wt}$ \% $\mathrm{Ti}$ as shown in SEM and optical images (Figures $6 \mathrm{a}$ and $6 \mathrm{~b}$ ). The effect of

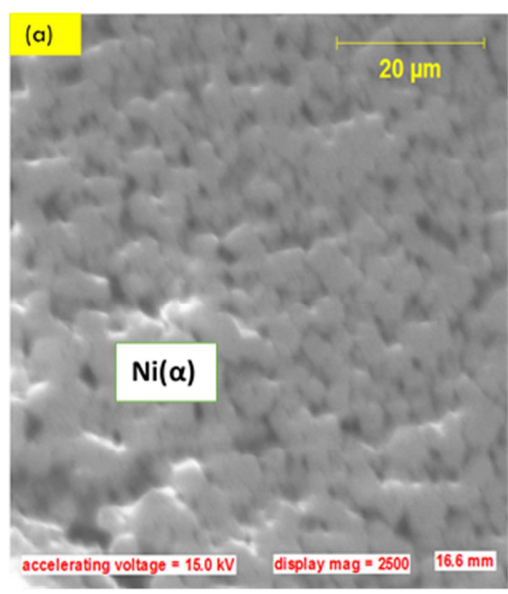

the Ti addition can be deduced from the total transformation with the grain size and widespread distributions by the formed phases. The primary phase formed as solidification began was the $\tau$ phase. This phase was followed by the crystallization of Ni-Ni3B- $\tau$ ternary eutectic. These phases are shown in the SEM (Figure 6a) and OM (Figure 6b) images for Alloy C. Figures $7 \mathrm{c}$ and $7 \mathrm{~d}$ shows the EDXA spectra for the main $\tau$ and $\mathrm{Ni}-\mathrm{Ni}_{3} \mathrm{~B}-\tau$ phases. It should be emphasized that for the alloys without the Ti addition, the primary phase observed on the microstructure was the $\mathrm{Ni}(\alpha)$ phase. While the addition of titanium to this Ni-B binary led to the formation of other hard phases, which effect reflected most in this work at the at highest Ti addition of $11 \mathrm{wt} . \%$.

Another very important observation is the evolution of the grain size and distribution in the alloys. The size of the grains making up the alloy microstructure is observed to reduce with the addition of the titanium to the Ni-B binary alloy. The control alloy is observed to be constituted of relatively larger grain of primary $\mathrm{Ni}(\alpha)$ phase bounded by $\mathrm{Ni}-\mathrm{Ni}_{3} \mathrm{~B}$ phases. Studies have shown that grain size reduction usually have positive impact on the mechanical or generally the physical properties of the metal matrix alloys or ceramic composites, while grain growth during sintering or alloying process does have detrimental effect. Thus, the more reduced the grain size during material processing, the better the structural properties such as hardness, wear, corrosion etc. In this work, reduction in grain size of the phases was achieved with $\mathrm{Ti}$ addition, and it is indicated that the $\mathrm{Ti}$ enhanced the physical properties of Alloy A, B and C.

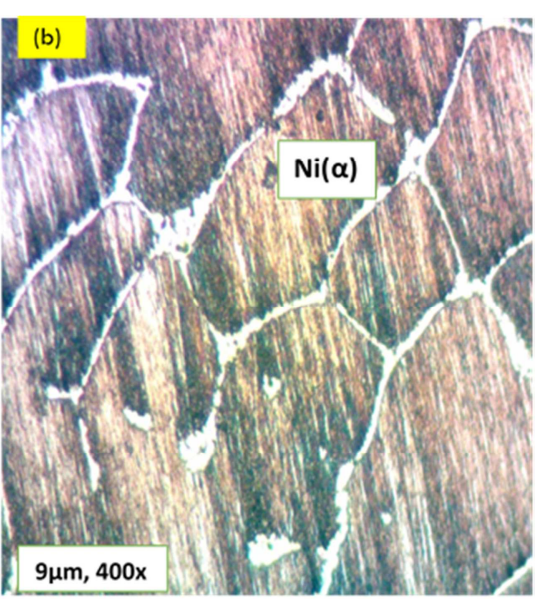

Figure 2. Micrographs of Quenched Control Sample (Ni-10B-OTi). (a) SEM and (b) optical microscope.

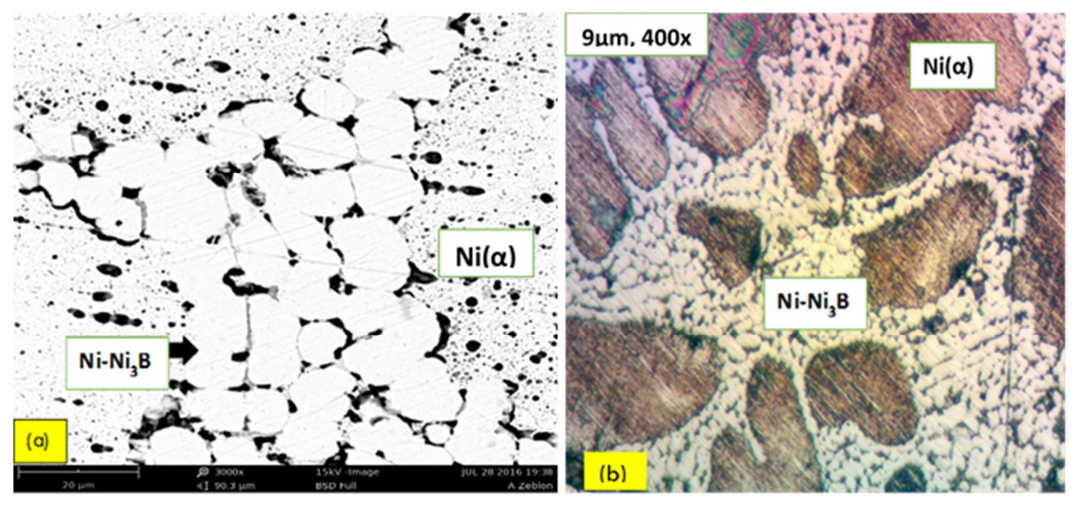

Figure 3. Micrographs of Alloy A containing 2 wt. \% Ti. (a) SEM and (b) optical microscopy. 

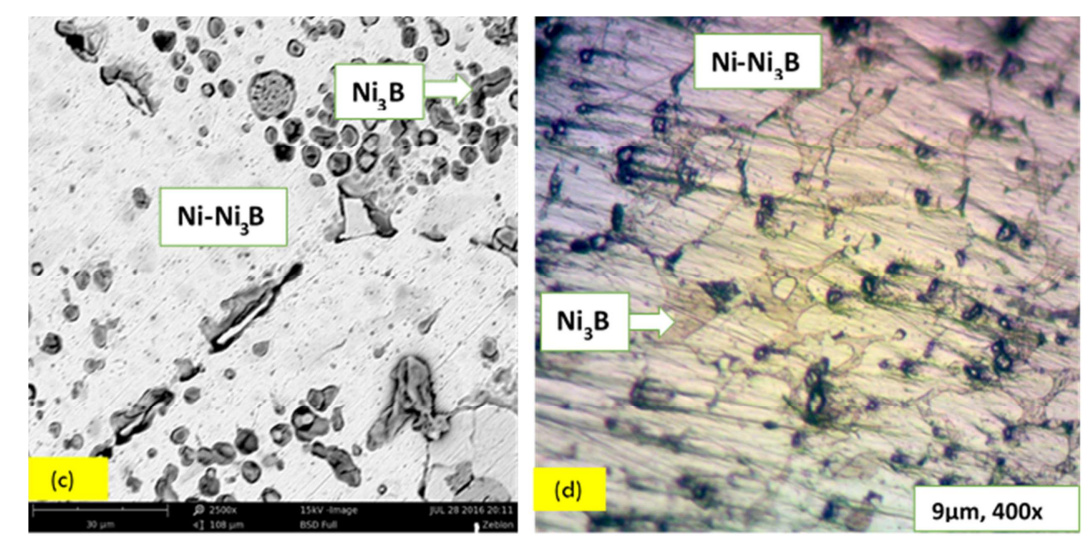

Figure 4. Micrographs of Alloy B containing 3wt. \% Ti. (c) SEM and (d) optical microscope.
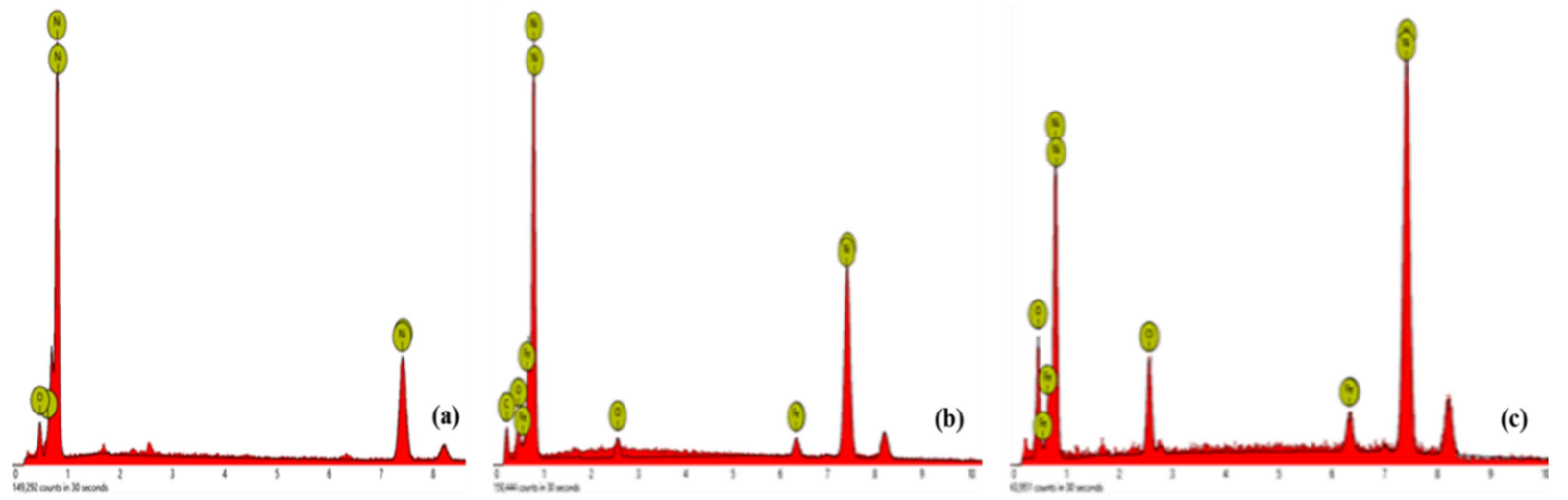

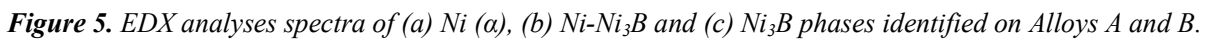
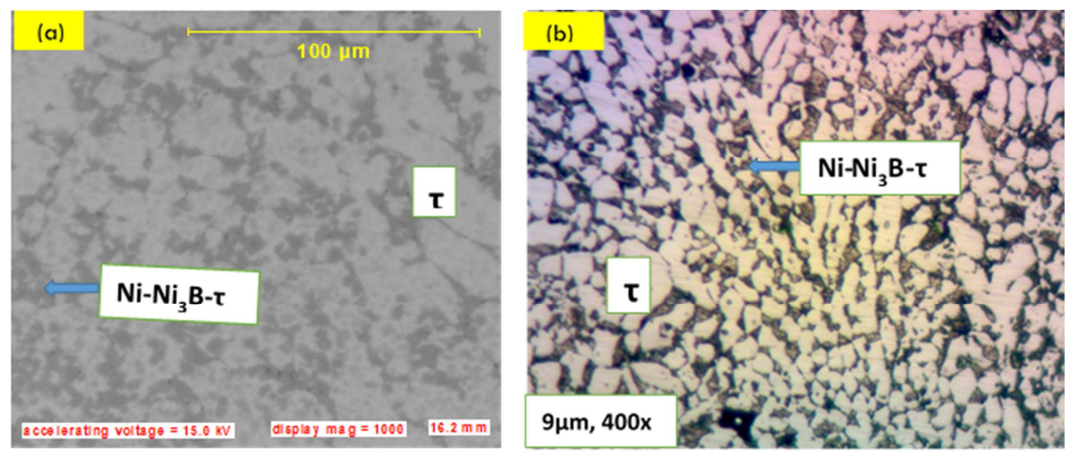

Figure 6. Micrographs of Alloy C containing 11wt. \% Ti (a) SEM and (b) Optical microscopy.
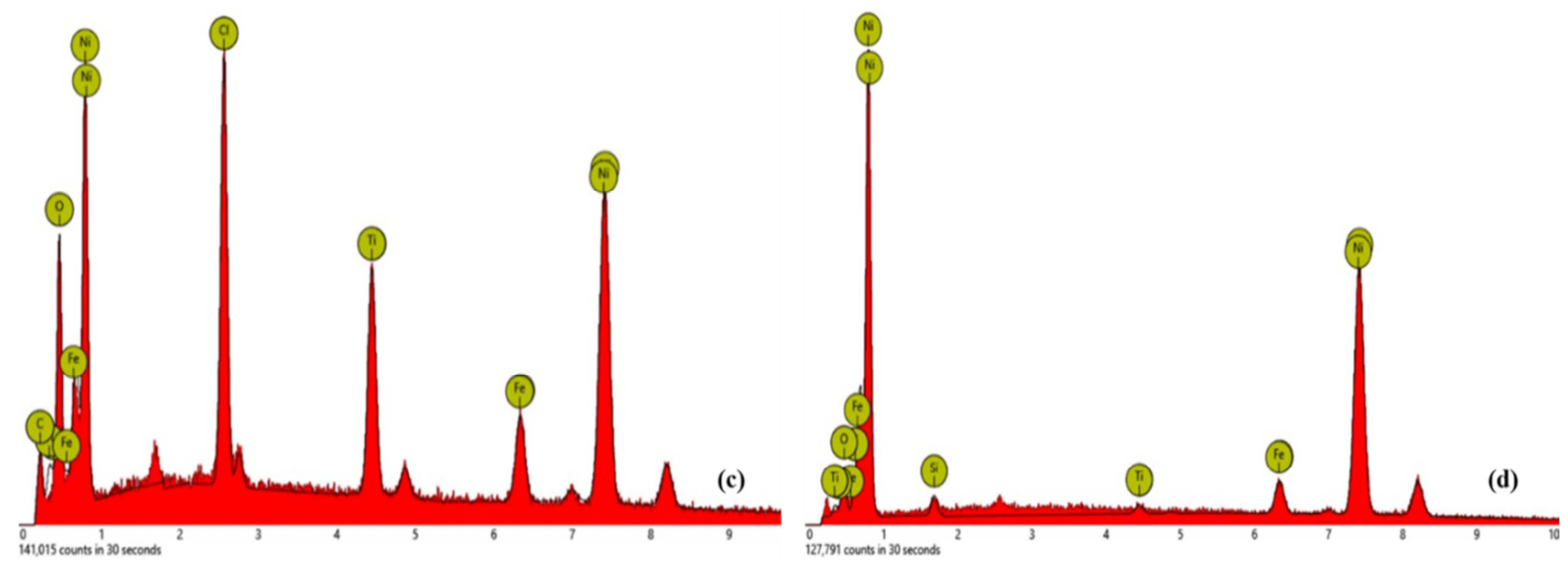

Figure 7. EDX analyses spectra of the (c) $\tau$ phase and (d) $\mathrm{Ni}_{-} \mathrm{Ni}_{3} \mathrm{~B}-\tau$ phase in Alloy $\mathrm{C}$. 


\subsection{Microhardness of the Alloys}

The hardness values of the alloys are presented in Table 2 . A plot of the hardness values of the alloys as a function of the titanium contents is shown in Figure 8. It can be seen that the hardness values increased as the titanium contents increased. Experimental results indicated that the microhardness of Ni-B alloy samples with Ti additions had higher hardness values compared to the control alloy Ni-10B. Similar observations has been reported in literatures [46, 49]. The very high microhardness exhibited by Alloy C (11 wt. \% Ti) is a result of large amount of Ti elemental powder that was well dispersed within the Ni-based ternary resulting in increased volume fraction of hard boride phases known for high hardness. The wide gap between the microhardness values of the alloys is as a result of the wide difference in concentrations of titanium additions in the ternary alloy samples. Also, the introduction of Ti in Ni-B binary matrix enhances its mechanical properties by the suppression of grain growth during melting and recrystallization, which led to the propagation of the fine-grained microstructure of intermetallic boride phases such as Ni3B, Ni-Ni3B- $\tau, \tau$ and Ni3B [50].

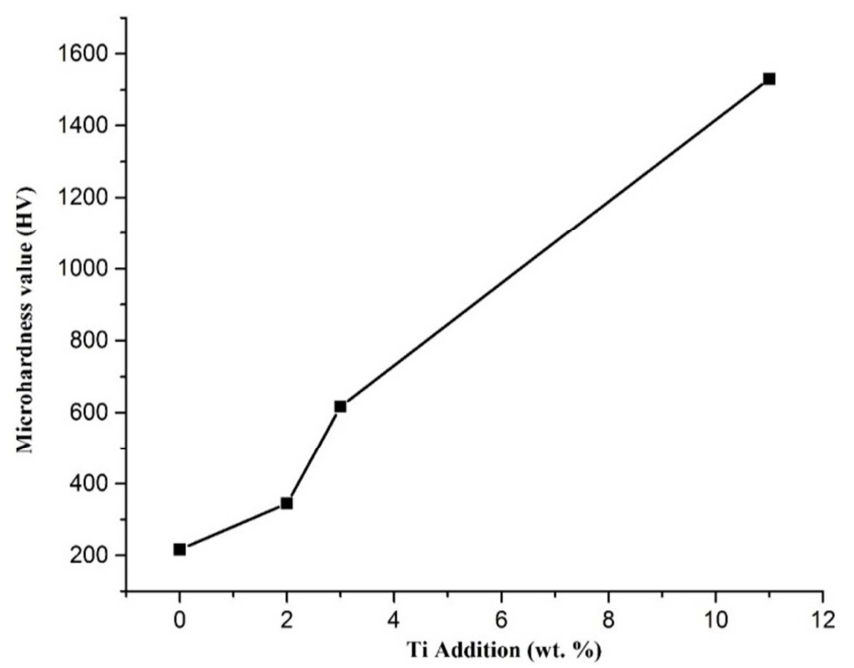

Figure 8. Average hardness values of the alloys as a function of the titanium contents.

\subsection{Stiffness of the Alloys}

Stiffness is the rigidity of an object, which is the extent to which it resists deformation in response to an applied force. The stiffness of an alloy is of high significance in various engineering applications, hence the modulus of elasticity is often one of the primary characteristics considered when selecting a material. A high stiffness is required when deflection is detrimental to the design, while a low modulus of elasticity is required when flexibility is necessary. In this work, high hardness of the alloy is desirable. The results obtained from the compressive tests performed on the alloy samples are presented in Table 3. A plot of the variation of elastic moduli with titanium content is shown in Figure 9. The stiffness of the alloys can be deduced from the elastic modulus plot, and it is shown to increase with increase in the titanium content. What this means is that as we add more titanium to the nickel-boron matrix, the matrix becomes stiffer. This is attributed to the formation of harder boride phases and most importantly the reduction in grain sizes of these alloys as we add more titanium to alloys. It may also be attributed to the formation of pockets of titanium boride hard phases in these alloys as we add more titanium.

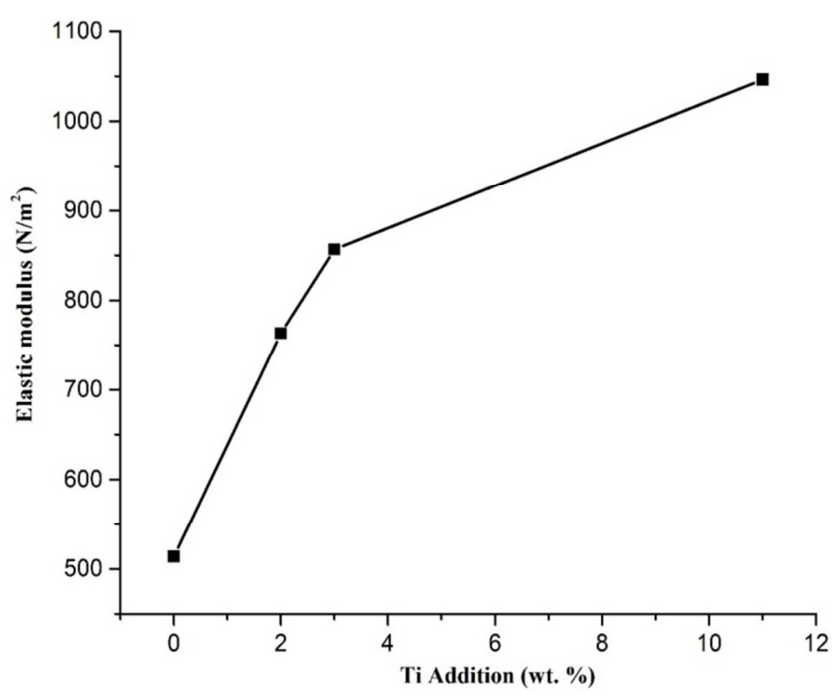

Figure 9. A plot of the variation of elastic moduli with titanium content in the alloys.

Table 2. Average hardness values of the Ni-based alloys investigated.

\begin{tabular}{lllll}
\hline Samples & First HV & Second HV & Third HV \\
\hline Control & 218.8 & 212.2 & 217.5 & Average HV \\
Alloy A & 339.1 & 335.1 & 359.4 & 34.2 \\
Alloy B & 639.4 & 627.3 & 583.1 & 616.6 \\
Alloy C & 1675.9 & 1556.8 & 1359.5 & 1530.7 \\
\hline
\end{tabular}

Table 3. Compressive test results of the alloys investigated.

\begin{tabular}{llll}
\hline Sample & Maximum compressive stress (MPa) & Compressive strain at maximum compressive stress & Elastic modulus (N/m ${ }^{2}$ ) \\
\hline Control & 82.62908 & 0.16083 & 513.77 \\
Alloy A & 354.18392 & 0.46412 & 763.13 \\
Alloy B & 185.12663 & 0.21611 & 856.63 \\
Alloy G & 353.06255 & 0.33737 & 1046.51 \\
\hline
\end{tabular}




\section{Conclusion}

In this study, binary Ni-B and ternary Ni-B-Ti alloys with varied $\mathrm{Ti}$ addition were prepared using high temperature furnace melting, while the influence of Ti additions to the NiB based ternary alloys have been studied using microstructural, elemental and mechanical characterization techniques. It is observed that addition of $\mathrm{Ti}$ to the $\mathrm{Ni}-\mathrm{B}$ alloys led to the shifting of the alloys from the hypoeutectic to the hypereutectic region during quenching in air. Also, addition of Ti to the Ni-B alloys also led to the formation of hard boride and complex phases as discussed in the text. As show in the microstructure, titanium addition and increase in Ti concentrations induced steady reduction in grain size in the Ni-based alloys with the formation of two major primary phases $[\mathrm{Ni}(\alpha)$ and $\tau]$ and other binary and ternary eutectic structures, and were identified as contributing to the hardness of the ternary alloys. Increase in addition of $\mathrm{Ti}$ to the Ni-B alloys led to corresponding increase in the hardness and stiffness of the alloys.

\section{Acknowledgements}

The support of the Center for Energy Research and Development, and the Department of Physics and Engineering Physics, Obafemi Awolowo University, Ile-Ife, Nigeria is acknowledged.

\section{References}

[1] E. Lugscheider, O. Knotek and K. Klohn, "Development of Ni-Cr-Si base Filler Metals," J. Weld. Res. Supp. 57 (1978) 319-325.

[2] R. González, M. A. García, I. Peñuelas, M. Cadenas, M. D. R. Fernández, A. H. Battez and D. Felgueroso, "Microstructural study of NiCrBSi coatings obtained by different processes," Wear 263 (2007) 619-624.

[3] O. Knotek, E. Lugscheider and W. Wichert, "On the structure and properties of wear and corrosion resistant Ni-Cr-W-C-Si alloys," Thin Solid Films 53 (1978) 303-312.

[4] E. Fernández, M. Cadenas, R. González, C. Navas, R. Fernández and J. d. Damborenea, "Wear behaviour of laser clad NiCrBSi coating," Wear 259 (2005) 870-875.

[5] E. Ajenifuja, G. A. Osinkolu, A. Y. Fasasi, D. A. Pelemo and E. I. Obiajunwa, "Rutherford backscattering spectroscopy and structural analysis of DC reactive magnetron sputtered titanium nitride thin films on glass substrates," J Mater Sci: Mater Electron 27 (2016) 335.

[6] E. Ajenifuja, A. P. I. Popoola and O. M. Popoola, "Thickness dependent chemical and microstructural properties of DC reactive magnetron sputtered titanium nitride thin films on low carbon steel cross-section," J. Mater. Res. Technol., (2018). doi.org/10.1016/j.jmrt.2018.02.010.

[7] O. Knotek, H. Reimann and P. Lohage, "Reactions between Ni-Cr-B -Si matrixes and carbide additives in coating during fusion treatment," Thin Solid Films, 83 (1981) 361-367.
[8] M. E. Zeblon, E. Ajenifuja and J. A. Ajao, "Thermal and Microstructural Study of Slowly Cooled Ni-B Hard Alloys Containing," J. Mater. Res. Technol. (2018). doi.org/10.1016/j.jmrt.2017.09.011

[9] J. A. Ajao, "Phase transitions in some nickel-rich nickelboron-titanium hard alloys," J Alloys Compd. 493 (2009) 314-321.

[10] J. A. Ajao, "Preparation and structural characterization of vanadium doped Ni-B binary hard alloys," J. Minerals \& Mater Characterization \& Eng. 9 (2010) 559-568.

[11] F. Otsubo, H. Era and V. (. Kishitake, "Structure and phases in Nickel-base self fluxing alloy coating containing high chromium and boron," J Ther Spray Technol. 9 (2000) 107-113.

[12] A. N. Campbell, A. W. Mullendore, C. R. Hills and J. B. Vandersande, "The effect of boron on the microstructure and physical properties of chemically vapour deposited Nickel Films," J of Mater Sci. 23 (1988) 4049-4058.

[13] Y. Wang and W. Chen, "Microstructures, properties and hightemperature carburization resistances of HVOF thermal sprayed NiAl intermetallic-based alloy coatings," Surf Coat Technol. 183 (2004) 18-28.

[14] T. S. Sidhu and S. Prakash, "Hot corrosion and performance of nickel-based coatings," Current Sci 90 (2006) 41-47.

[15] Y. I. An, H. Y. Du, Y. H. Wei, N. Yang, L. F. Hou and W. M. Lin, "Interfacial structure and mechanical properties of surface iron-nickel alloying layer in pure iron fabricated by surface mechanical attrition alloy treatment," Materials \& Design, 46 (2013) 627-633.

[16] S. Lebaili, J. A. Ajao and S. Hamar-Thibault, "Preparation and characterization of meltspun nickel-based alloys containing heavy metals," J Alloys Compd. 188 (1992) 87-93.

[17] L. Battezzati, C. Antonione and M. Baricco, "Undercooling of $\mathrm{NiB}$ and FeB alloys and their metastable phase diagrams," J Alloys Compd. 247 (1997) 164-171.

[18] A. Contreras, C. Leon, O. Jimenez, E. Sosa and R. Perez, "Electrochemical behavior and microstructural characterization of $1026 \mathrm{Ni}-\mathrm{B}$ coated steel," Applied Surf. Sc. 253 (2006) 592-599.

[19] K. Krishnaveni, T. S. N. Sankara Narayanan and S. K. Seshadri, "Electroless Ni-B coatings: preparation and evaluation of hardness and wear resistance," Surf. Coat. Technol. 190 (2005) 115-121.

[20] V. Vitry, A. F. Kanta, J. Dille and F. Delaunois, "Wear and corrosion resistance of heat treated and as-plated duplex NiPNiB coatings on 2024 aluminium alloy," Surf. Coat. Technol. 206 (2012) 3444-3451.

[21] B. Oraon, G. Majumdar and B. Ghosh, "Parametric optimization and prediction of electroless Ni-B deposition.," Mater. \& Design, 28 (2007) 2138-2145.

[22] B. Oraon, G. Majumdar and B. Ghosh, "Improving hardness of electroless $\mathrm{Ni}-\mathrm{B}$ coatings using optimized deposition conditions and annealing," Mater. \& Design, 29 (2008) 14121418 .

[23] T. S. N. Sankara Narayanan, A. Stephan and S. Guruskanthan, "Electroless Ni-Co-B ternary alloy deposits: preparation and characteristics," Surf. Coat. Technol. 179 (2004) 56-62. 
[24] Y. N. Bekish, S. K. Poznyak, L. S. Tsybulskaya and T. V. Gaevskaya, "Electrodeposited Ni-B alloy coatings: structure, corrosion resistance and mechanical properties," Electrochimica Acta, 7 (2010) 2223-2231.

[25] K. Krishnaveni, T. S. N. Sankara Narayanan and S. K. Seshadri, "Electrodeposited $\mathrm{Ni}-\mathrm{B}-\mathrm{Si}_{3} \mathrm{~N}_{4}$ composite coating: Preparation and evaluation of its characteristic properties," J. Alloys Compd. 466 (2008) 412-420.

[26] F. Delaunois, J. P. Petitjean, P. Lienard and M. J. Duliere, "Autocatalytic electroless nickel-boron plating on light alloys," Surf. Coat. Technol. 124 (2000) 201-209.

[27] T. S. N. Sankara Narayanan and S. K. Seshadri, "Formation and characterization of borohydride reduced electroless nickel deposits," J. Alloys Compd. 365 (2004) 197-205.

[28] T. S. N. Sankara Narayanan, K. Krishnaveni and S. K. Seshadri, "Electroless Ni-P/Ni-B duplex coatings: preparation and evaluation of microhardness, wear and corrosion resistance," Mater. Chem. Phy. 82 (2003) 771-779.

[29] K. M. Gorbunova, M. V. Ivanov and V. P. Moiseev, "Electroless deposition of Nickel - Boron alloys mechanism of process, structure, and some properties of deposits," J. Electrochem. Soc. 120 (1973) 613-618.

[30] C. R. Das, S. K. Albert, A. K. Bhaduri, C. Sudha and A. L. E. Terrance, "Characterisation of nickel based hardfacing deposits on austenitic stainless steel," Surface Engineering, 21 (2013) 290-296.

[31] S. Atamert and H. K. D. H. Bhadeshia, "Nickel based hardfacing alloys for high temperature applications," Materials Science and Technology 12 (2013) 1220-1228.

[32] K. Gurumoorthy, M. Kamaraj, K. P. Rao and S. Venugopal, "Microstructure and wear characteristics of nickel based hardfacing alloys deposited by plasma transferred arc welding," Materials Science and Technology 22 (2013) 975980.

[33] C. R. Das, S. K. Albert, A. K. Bhaduri and R. Nithya, "Effects of dilution on microstructure and wear behaviour of $\mathrm{NiCr}$ hardface deposits," Materials Science and Technology 23 (2013) 771-779.

[34] L. J. da Silva and A. S. C. M. D’Oliveira, "NiCrSiBC alloy: microstructure and hardness of coatings processed by arc and laser," Welding International 31 (2016) 1-8.

[35] W. Wu and L. T. Wu, "The wear behavior between hardfacing materials," Metallurgical and Materials Transactions A 27 (1996) 3639-3648.

[36] P. Aubry, C. Blanc, I. Demirci, M. Dal, T. Malot and H. Maskrot, "Analysis of nickel base hardfacing materials manufactured by laser cladding for sodium fast reactor," Physics Procedia 83 (2016) 613-623.
[37] M. J. Donachie, Titanium: A Technical Guide, USA: ASM International, 2000.

[38] G. Lutjering and J. C. Williams, Titanium, Berlin, Germany: Springer Verlag, 2007.

[39] S. Ankem and C. A. Greene, "Recent Development in Microstructure/Property Relationships of Beta Titanium Alloys," Materials Science and Engineering A 263 (1999) 127-131.

[40] O. M. Ivasishin, P. E. Markovsky, Y. V. Matviychuk, S. L. Semiatin, C. H. Ward and S. Fox, "A Comparative Study of the Mechanical Properties of High Strength Beta Titanium Alloys," J. Alloys Compd 457 (2008) 296-309.

[41] V. J. Tennery, C. B. Finch, C. S. Yust and G. W. Clark, Science of Hard Materials, New York: Plenum, 1983.

[42] Z. Muzaffer and K. Erdem, "Influence of Ti addition on the microstructure and hardness properties of near-eutectic $\mathrm{Al}-\mathrm{Si}$ alloys," J. Alloys Compd 450 (2008) 255-259.

[43] R. A. Shakoor, R. Kahraman, U. S. Waware, Y. Wang and W. Gao, "Synthesis and properties of electrodeposited Ni-B-Zn ternary alloy coatings," Int. J Electrochem. Sci. 9 (2014) 5520 -5536 .

[44] J. Schobel and H. Stadelmaier, "The Nickel-Boron-Titanium Ternary System," Metallurgy 7 (1965) 715-719.

[45] N. Saheb, T. Laoui, A. R. Daud, M. Harun, S. Radiman and R. Yahaya, "Influence of Ti addition on wear properties of Al-Si eutectic Alloys," Wear 249 (2001) 656-662.

[46] C. Viega, J. P. Davim and A. J. R. Loureiro, "Properties and applications of titanium alloys," Rev. Adv. Mater. Sc. 32 (2012) 133-148.

[47] S. Hou, Z. Liu, D. Liu and Y. Ma, "Oxidation Behavior of $\mathrm{NiAl}^{-\mathrm{TiB}_{2}}$ Coatings Prepared by Electrothermal Explosion Ultrahigh Speed Spraying," Physics Procedia, 32 (2012) 7177.

[48] A. P. I. Popoola, S. L. Pityana and O. M. Popoola, "Microstructure and corrosion properties of $\mathrm{Al}\left(\mathrm{Ni} / \mathrm{TiB}_{2}\right)$ intermetallic matrix composite coatings," The Journal of The Southern African Institute of Mining and Metallurgy 111 (2011) 345-353.

[49] R. G. Munro, "Material Properties of Titanium Diboride," J. Res. Natl. Inst. Stand. Technol. 105 (2000) 709-720.

[50] M. N. Mokgalaka, S. L. Pityana, A. P. I. Popoola and T. Mathebula, "NiTi Intermetallic Surface Coatings by Laser Metal Deposition for Improving Wear Properties of Ti-6Al-4V Substrates," Advances in Materials Science and Engineering 2014 (2014) 1-8. 